УДК 339:338:711

JEL classification: 0 14; 031

DOI: https://doi.org/10.35774/visnyk2020.02.050

\author{
Ruslana LUTSIV, \\ PhD student of the Department of International Relations \\ Ternopil National Economic University \\ 11 Lvivska str., Ternopil, Ukraine, 46009, \\ e-mail: ruslana1821@gmail.com \\ ORCID ID: 0000-0002-1026-7847
}

\title{
SMART CITIES: ECONOMIC DIMENSIONS OF THEIR EVOLUTION
}

Lutsiv R. (2020). Smart cities: Economic dimensions of their evolution. [«Rozumni mista»: ekonomichni vymiry evoliutsii]. The Herald of Ternopil National Economic University, Vol. 2. P. 50-61. DOI: https://doi.org/10.35774/visnyk2020.01.050

Луців Р. «Розумні міста»: економічні виміри еволюції. Вісник Тернопільського національного економічного університету. 2020. Вип. 2. С. 50-61. DOI: https://doi. org/10.35774/visnyk2020.01.050

\section{Abstract}

Introduction. With the increase in urban population and the growth of citizens' expectations, the development of smart cities - with the support and integration of digital technologies - should become one of the greatest achievements of humanity in the 21 st century.

Cities on our planet, from small regional communities to global mega-hubs, from the most ancient cities to the modern ones, focus on developing and implementing smart city initiatives to make them more efficient, sustainable, attractive to citizens and stimulate economic growth.

Methods. Comparative and critical analysis was used to identify patterns of smart city generations formation and to find the problems of their functioning in different corners of our planet. Additionally, the mentioned methods and the method of modeling helped us to highlight the components of the concept presented through the drawing and enabled the visual presentation of its generations' characteristics in the table.

Results. The essence of the concept of "smart city", its theoretical and applied aspects are considered. The main characteristics of the smart cities generations are defined as an innovative model for managing the socio-economic development of large cities. The most successful projects of smart city implementation in the world in such cities as Santander, Songdo, Masdar, Rio de Janeiro and Singapore are analyzed. It is proved that smart city is a modern model of urban transformation with the use of information and communication

(C) Ruslana Lutsiv, 2020. 
technologies for solving the most complex problems and development of innovations, active involvement of the citizens in the transformation process. It is a place where conditions for the development of the community and every person are created as a key driving force in fostering economic and social growth in which information technologies allow to change qualitatively the management system.

Discussion. The prospects for further development of the study are to explore the experience of implementing Generation 3.0 in the top world smart cities and ways of its introduction in Ukraine, as this is the key to the economic uplift and social progress of the world.

Keywords: smart city; smart buildings; economic and environmental sustainability; agglomeration; smart economy.

Formulas: 0, fig.: 1, tabl.: 1, bibl.: 31 .

\section{Анотація}

Руслана ЛУЦІВ

\section{«РОЗУМНІ МІСТА»: ЕКОНОМІЧНІ ВИМІРИ ЕВОЛЮЦІї}

Вступ. Зі збільшенням кількості міського населення і зростанням очікувань громадян, розвиток «розумних міст» - із підтримкою та інтеграцією цифрових технологій - має стати одним із найголовніших досягнень людства у XXI cm.

Міста нашої планети, від невеликих регіональних громад до глобальних мегавузлів і від найдревніших міст до нових, фрокусуються на розробиі та впровадженні ініціатив "розумного міста», щоб зробити їх більш ефективними, стійкими, привабливими для громадян і стимулювати економічне зростання.

Meтоди. У науковій розвідці використано методи компаративного та критичного аналізів для виявлення закономірностей формування поколінь «розумних міст» та проблем їхнього функціонування у різних куточках нашої планети; а також для виокремлення складових концепції, яку,' за допомогою методу моделювання представлено у вигляді рисунка, та характеристик ї̈ поколінь і їхньої візуальної презентації у таблиці.

Результати. Розглянуто сутність концепції «розумного міста», ї̈ теоретичні та прикладні аспекти. Визначено основні характеристики поколінь «розумних міст» як інноваційної моделі управління соціально-економічним розвитком великих міст. Проаналізовано особливості, зокрема найбільш успішні проєкти, впровадження проєктів «розумного міста» у світі у таких містах, як Сантандер, Сонгдо, Масдар, Ріо-де-Жанейро та Сінгапур. Доведено, що «розумне місто» - це сучасна модель міської трансформації з використанням інформаційно-комунікаційних технологій для вирішення найскладніших проблем та розвитком інновацій, активним залученням громадян до перетворення міста у місце, де б створювалися умови для розвитку громади і кожної людини, як ключової рушійної сили економічного та соціального зростання, в якій інформаційні технології дають змогу якісно змінити систему управління.

Перспективи. Перспективи подальшого розвитку дослідження полягають у вивченні досвіду імплементації концепції 3.0 у містах, які очолюють світові 
рейтинаи «розумних міст» та шляхи втілення в Україні, адже це $\epsilon$ запорукою економічного піднесення та суспільного прогресу як нашої держави, так і світу.

Ключові слова: «розумне місто»; «розумні будівлі»; економічна та екологічна стійкість; агломерація; «розумна економіка»

Формули: 0, рис.: 1, табл.: 1, бібл.: 31.

Introduction. According to the UN Economic and Social Council, by $205068 \%$ of the world's population will live in cities. Today, the 600 largest urban areas already account for $60 \%$ of the world GDP. According to experts, up to $80 \%$ of future economic growth in developing regions will occur only in cities [1]. The majority of the world's population lives in cities, where the impact of urbanization on all spheres of lives is observed [2]. In many countries, people's daily lives are becoming simpler, fuller, and safer with previously unavailable digital services. The global smart city market is projected to reach $\$ 463.9$ billion by 2027, with a compound annual growth rate (CAGR) of $24.7 \%$ from 2020 to 2027 . Today, the phrase "smart city" has become one of the most common in both everyday and scientific literature. Together with e-government and, for example, telemedicine, unmanned vehicles, this term represents the near future - a world in which many problems of urban areas have been overcome thanks to information technology.

Literature Review. The concept of "smart city" continues to be utterly novel, however, in scientific thought, specifically, among foreign scientists, there are many different approaches to understanding this phenomenon. Both European research institutions and powerful IT companies mostly deal with the applied issues of developing the concept of "smart city" [3-5]. It is worth noting the usefulness of the study of Internet resources on varied aspects of the functioning of the smart city [3, 6-9]. Also, the basis for highlighting the peculiarities of the implementation of smart city technologies were the works of S. Goldenberg, R. Giffinger et al., T. Hall and T. Nam [2, 10-11]. There are numbers of scientific publications on different aspects of smart city projects implementation [11-14, 16].

Purpose. The article aims to explore the essence, main characteristics, and development of the concept of "smart city" as an innovative model of management of socioeconomic development of cities, as well as to analyze the experience and features of its implementation in several cities around the world.

Results. Smart cities address a variety of issues such as efficient transportation, smart and improved buildings, and housing, optimal energy use, and better administrative services. The development of new technologies that will be involved in urban management processes will also contribute to market growth.

The concept of a "smart city" aims to reduce problems, such as waste disposal, environmental pollution, or trying to get as much space as possible, arising from urban population growth and rapid urbanization [17]. The system is based on information and communication technologies (ICT) and digital technologies [18]. Generation 3.0, in particular, tries to combine three key factors: technology, citizens, and city administrations [19]. The goal of development is to create a more liveable city, achieve economic, social, and environmental sustainability, reduce costs and consumption of resources, and more active integration of citizens [2]. 
"A Smart City is an agglomerated area affected by a high concentration of learning and innovation as a result of creative citizens and institutions, as well as the implementation of digital infrastructure with the overall objective of achieving economic growth and high quality of life while keeping in mind scarcity of natural resources" [20, p. 214]. Therefore, the main components of the concept of a "smart city" are:

- smart economy based on high-tech industries that include ICT. E-business and e-commerce, and productivity growth are integral components of the smart city economy;

- smart citizens are highly educated and highly qualified residents who are actively involved in the public life of the city;

- smart governance is a diversified e-government system for interaction with citizens. In the smart city the delegation of functions and diversification of power is the basis of social interaction of various institutions;

- smart mobility is innovative and safe transport and logistics systems based on ICT infrastructure that improve urban traffic and mobility of urban residents in everyday life;

- smart environment is closely linked to energy. After all, the key is the principle of energy efficiency and reduction of greenhouse gas emissions, as well as measures to protect the environment;

- smart living is control of climate, ventilation, light, all electrical appliances, and security system with a single remote control or smartphone.

Figure 1 presents the components of the concept of "smart city", which are described above.

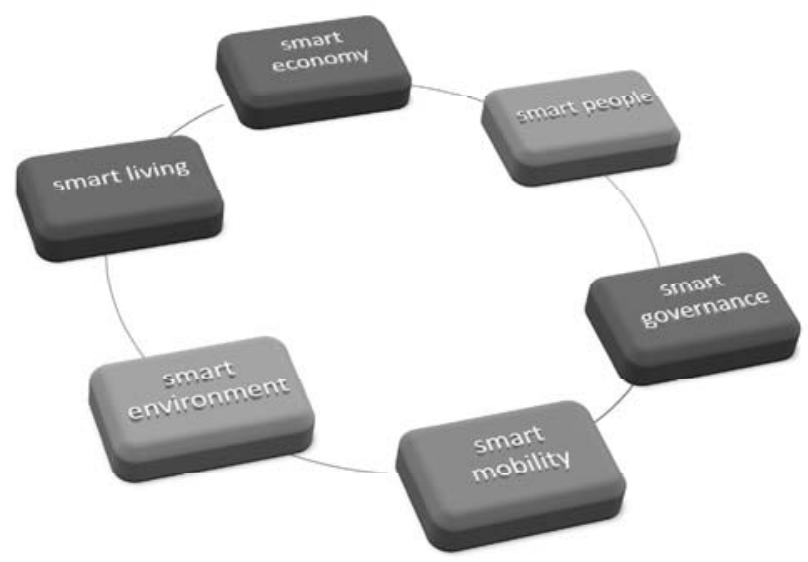

Fig. 1 Components of the concept of "smart city"

Source: developed by the author based on [10].

A modern developed city is the driving force of any country's economy, a center of culture, education and science, a platform for the implementation of technological and social innovations. That is why today the development of comfortable infrastructure directly affects the economic performance of the city, determines its attractiveness for qualified professionals and investors, which, in turn, contributes to a significant increase in competition among cities. Big cities have always been and will remain centers of civilization development. 
The term "smart city", which appeared in the late "90s, was originally used only to define environmental friendliness and was associated with "green" technologies. In the early 2000s, the emphasis shifted to IT tools with which the smart city manages data and ultimately improves the quality of life. A smart city is "the effective integration of physical, digital and human systems in the built environment to deliver a sustainable, prosperous and inclusive future for its citizens," according to a report by the British Standards Institution (BSI) [3, p.4]. For any smart city, such components as sensors and sensor systems are required, as with their help the digital ecosystem of the smart city receives data from users and various city systems [6]. Life support and all processes within the city infrastructure are regulated by a digital platform [7]. Residents and social institutions are also an integral part of the smart city, and technology is only a tool to achieve these goals.

Besides, the smart city serves as a feedback system for authorities and service developers, which takes into account the opinion of every citizen. Reaching the level of a smart city is a long process with no time limits. Therefore, it is only possible to guess how successfully and which of the elements of the concept of "smart city" are used in a particular locality. The wider and more successful the use of technologies to solve management problems, improve the quality of life and save resources is, the "smarter" the city. And the process of "smarting" can continue as long as there is a city.

It is impossible to create a smart city without the use of certain technologies. In the early 2000s models and programs were developed to analyze vast amounts of data from many different sources. During that period an English term "Big data" that defines such amounts of information and methods of working with it" was coined. Experts have learned to identify hidden, in these digitized collapses of data, patterns and make conclusions and forecasts based on them. In 2009, the term Big Data first appeared in the media, and in 2013, researchers began to write and talk about Big Data in the scientific community [8].

The Internet of Things (IOT) plays an important role in the development and implementation of the concept of a "smart city". IoT is an abbreviation used for the socalled "Internet of Things" [9]. "It's a continuous stream of data that starts with us [people], the home and work environment, the urban infrastructure - and eventually ends on the global network," defined this phenomenon Rob van Kronenburg, the author of the concept of the Internet of Things, founder of the European Council "Internet of Things", an expert in the field of digitalization [4]. In other words, it is a world in which all objects are connected via the Internet by electronic tags, barcodes, sensors, wires, and radio channels. This also includes programs that combine all the units and technologies of Big Data. The third generation of mobile communication (3G) allows us to meet most of the needs of users: browsing sites, communicating on social networks and messengers, online games, navigation, downloading applications, and watching videos. 4G solves the problems that arise when watching videos online in high resolution and transmitting large amounts of information. But the concept of a "smart city" requires the introduction of $5 \mathrm{G}$ networks, where data rates are no longer the main parameter. The priority is continuous coverage of areas and Internet access in the most inaccessible places. The uninterrupted simultaneous operation of a huge number of devices in the network is important as well. This component of the smart city includes all sorts of sources of information: cameras and video cameras, motion sensors, temperatures, air pollution, noise levels, etc. 
Creating a smart city requires the coordinated work of a huge number of professionals. In particular, government officials who understand why this needs to be done and provide funding, resources, and infrastructure allocation managers, big data analysts, sociologists, human behaviorists, and others. Besides, this process requires trained citizens as well. If the majority of the population does not own the technology, then due to conservatism they may not accept the services that are necessary for the implementation of the concept of "smart city". Therefore, the consistent and continuous preparation of the citizens of the smart city life is a task that requires time, patience, and efforts.

The beginning of the era of smart cities is associated with the Spanish resort of Santander with a population of 172 thousand inhabitants in 2018. The capital of the Cantabria region was the first in Europe to dare to introduce new technologies. At the beginning of the SmartSantander project in 2011, information was processed from 16,000 sensors installed in the city center. Besides, a broadcasting network and a platform for information processing have been set up. The sensors reported air pollution, traffic intensity, free parking spaces, filling of garbage containers, etc. In total, more than ten high-tech projects with a budget of 60 million euros were implemented. The mayor's office used the information to save street lighting, improve waste collection, and unload roads to avoid traffic jams. As a result, in addition to the obvious improvement in the lives of citizens, the number of jobs for specialists in the field of information technology has increased [12].

Urban expert Bill Hutchinson proposed a classification of smart city generations 1.0, 2.0, and 3.0 [21]. In smart city 1.0, there is no general strategy, separate, unconnected components are automated. Generation 2.0 combines and interconnects previously independent initiatives and maximizes different sources of information. Generation 3.0 assumes that the integration of all components is complete, and the entire infrastructure is like a web intertwined with intelligent technology (Table 1).

Table 1

\section{Smart City Generations}

\begin{tabular}{|c|c|c|c|}
\hline Characteristics & $\begin{array}{c}\text { Smart city } 1.0 \\
\text { Efficient infrastructure }\end{array}$ & $\begin{array}{c}\text { Smart city } 2.0 \\
\text { Initial digitisation }\end{array}$ & $\begin{array}{c}\text { Smart city } 3.0 \\
\text { Digital Ecosystem }\end{array}$ \\
\hline $\begin{array}{l}\text { The main purpose } \\
\text { of technology } \\
\text { application }\end{array}$ & $\begin{array}{l}\text { - Improving the } \\
\text { resilience, liveability, and } \\
\text { manageability of the city. }\end{array}$ & $\begin{array}{l}\text { - Solving problems in healthcare, } \\
\text { transport, environment, and ecology } \\
\text { through the use of technology. }\end{array}$ & $\begin{array}{l}\text { - Formation of a single digital } \\
\text { ecosystem of technologies and } \\
\text { services for the exchange of } \\
\text { industry data. }\end{array}$ \\
\hline $\begin{array}{l}\text { Key tasks for the } \\
\text { development of a } \\
\text { smart city }\end{array}$ & $\begin{array}{l}\text { - Technological } \\
\text { re-equipment, } \\
\text { implementation of } \\
\text { advanced IT solutions. }\end{array}$ & $\begin{array}{l}\text { - Formation of the primary digital } \\
\text { architecture of the smart city. } \\
\text { - Introduction of Internet of Things } \\
\text { technologies. }\end{array}$ & $\begin{array}{l}\text { - Involvement of citizens and } \\
\text { providing favorable conditions for } \\
\text { joint activities. }\end{array}$ \\
\hline $\begin{array}{l}\text { Key players } \\
\text { in the city's } \\
\text { intellectualization }\end{array}$ & $\begin{array}{l}\text { - Providers of } \\
\text { technological solutions } \\
\text { and services. }\end{array}$ & $\begin{array}{l}\text { - City authorities. } \\
\text { - City residents are not fully } \\
\text { involved in city management. }\end{array}$ & $\begin{array}{l}\text { - Partnerships and collaborations of } \\
\text { business, government, citizens, and } \\
\text { technology companies. } \\
\text { - Active participation of city } \\
\text { residents in the introduction of new } \\
\text { technologies. }\end{array}$ \\
\hline $\begin{array}{l}\text { Infrastructure } \\
\text { development tasks }\end{array}$ & $\begin{array}{l}\text { - Semi-automated } \\
\text { infrastructure. }\end{array}$ & - Intelligent infrastructure. & $\begin{array}{l}\text { - Integrated intelligent } \\
\text { infrastructure that allows real-time } \\
\text { management of all processes in all } \\
\text { sectors of the economy. }\end{array}$ \\
\hline
\end{tabular}


End of Table1

\begin{tabular}{|c|c|c|c|}
\hline $\begin{array}{l}\text { Phys } \\
\text { infra }\end{array}$ & $\begin{array}{l}\text { Transport: } \\
\text { • centralized transport } \\
\text { monitoring and } \\
\text { management systems; } \\
\text { • electrified railways } \\
\text { and automation of main } \\
\text { railway lines. } \\
\text { Construction: } \\
\text { - modern standard } \\
\text { buildings; } \\
\text { • SAP design. } \\
\text { Energy: } \\
\text { • unidirectional electrical } \\
\text { networks }\end{array}$ & \begin{tabular}{|l|} 
\\
Construction: \\
- automated buildings; \\
- BIM design (Building Information \\
modeling) 1.0. \\
Energy: \\
- intelligent energy networks with \\
controlled loads and generation.
\end{tabular} & \begin{tabular}{|l|} 
Transport: \\
• interaction of all types of \\
transport; \\
• renewable energy for transport; \\
- unmanned control; \\
• autonomous service. \\
\\
Construction: \\
$\cdot$ BIM design (Building Information \\
modeling) 2.0, 3.0. \\
Energy: \\
$\cdot$ interconnected power distribution \\
and consumption systems; \\
$\cdot$ distribution of renewable energy \\
sources.
\end{tabular} \\
\hline Digital infrastructure & $\begin{array}{llr}- & \text { Wire } & \text { ground } \\
\text { communication. } & \\
\text { - Isolated data } & \text { collection } \\
\text { and processing } & \text { systems } \\
\text { based on } & \text { RFID } \\
\text { technologies. } & \end{array}$ & \begin{tabular}{|l}
$-\quad$ Smart networks, 3G / 4G, \\
broadband Internet access, optical \\
networks. \\
- Internet of Things, Big Data \\
analytics. \\
Digital infrastructure model, \\
intelligent management systems. \\
- Digital platforms for management \\
and service delivery for citizens and \\
businesses.
\end{tabular} & $\begin{array}{l}\text { - Semantic networks, merged } \\
\text { data, open data. } \\
\text { - Calculation of collected data. } \\
\text { - Cloud computing, sensor } \\
\text { networks in combination with } \\
\text { Web 2.0, and social networks. } \\
\text { - Digital platforms for managing } \\
\text { and providing services to } \\
\text { citizens. }\end{array}$ \\
\hline
\end{tabular}

Source: developed by the author based on Bill Hutchinson's classification [21].

The first generation of smart cities was built by large technology companies in the IT industry, which aimed to test their solutions. Fully adhering to the plans, smart houses were built in the new city, and intelligent energy and transport networks were laid. The aforementioned Santander, as well as cities such as Masdar in the UAE [13] and Songdo in South Korea [14], fall into this category. As a result, the Songdo International Business District was conceived by industrial giant Daewoo in the middle of the1990s and later bought by American developer Gale International and South Korean company POSCO E\&C. The project has been ongoing since 2003 , more than US $\$ 35$ billion has been invested, and it is completed by only $70 \%$. Network equipment for the city was developed by Cisco [5]. A central control unit has been created, and, based on the received data (RFID tags, sensors), regulates traffic flows and energy flows [20].

Gale International (an American real estate company) - the main shareholder and investor of the Songdo project - plans to spread such projects throughout Asia. Thus, the technological advances of Songdo are so great that they impress many scientists. However, they do not fully meet the city's goals of attracting global companies and employees from around the world. That is why a bridge was built to Incheon Airport, the country's largest transportation hub. But while the business district is home to 36,000 people, 90,000 live in Greater Songdo, but $99 \%$ of the people who bought housing in the city are Koreans. Young families come here because of the city's high-level schools. The comfortable city of Songdo is not so popular among employees as they do not like the "stone jungle" of the business district. The management of Gale International believes that it will be necessary to economically stimulate the company to relocate to the city. Besides, there is an outdated 
infrastructure between Songdo and Seoul as there are no high-speed trains and the only way to get to the capital is by car.

The implementation of the Masdar smart city eco-project in the UAE began in 2006 and should have been finished in 8 years - in 2014. The project, which was estimated at US $\$ 22$ billion and was partially invested by the state-owned company Mubadala, was developed by the British architectural firm Foster and Partners. However, officials have postponed the completion date until 2025. Besides, the project encountered many failures. However, many investors and companies see great potential in this city. Siemens opened its headquarters there, and the Massachusetts Institute of Technology (MIT) helped found the Masdar Institute of Science and Technology in 2009.

According to the architects [13], to ensure environmental friendliness, the city should use electric cars. The houses were designed to provide natural shade; on the street the controllers maintaining a comfortable temperature mode and allow to save on cooling. About 400 companies including Siemens, Mitsubishi Heavy Industries, partners of the GE Ecomagination initiative, and others have set up their offices in the business district, but mostly their presence there is formal.

Masdar City was conceived as a model of a green urban landscape and a global hub for the clean technology industry. Instead of getting energy by burning oil, coal, or gas, Masdar gets it from solar farms. The city also has a factory that uses solar energy to cool the water. It serves as a 50-ton air conditioner: the system supplies cooled air to the buildings throughout the city. Masdar city also has a tower over $45 \mathrm{~m}$ high, which directs the wind from the Persian Gulf to the city quarters, spraying a cool fog over the hot city. Masdar is also known for its unmanned electric vehicle system called Personal Rapid Transit. There are 13 automatic "capsules" of CyberCabs instead of cars or buses. They run from the outskirts to the city center. However, the completion of the Masdar project has been postponed to 2030 [11]. Unfortunately, to date only a $50 \%$ reduction in emissions has been achieved compared to other UAE cities.

Thus, it can be argued that smart city 1.0 is a municipality that maximizes the use of advanced technologies as a lever of liveability, stability, and control. These cities are often criticized for their technological focus and the influential role of large corporations such as IBM, CISCO, Siemens, and Mitsubishi Heavy Industries.

A comprehensive strategic vision for urban development is key to smart cities 2.0. Such projects require close cooperation between the city government and large technology companies. The key trend is the introduction of integrated urban infrastructure management systems that would allow monitoring and scheduling of critical facilities and prevent hazards. With the help of such solutions, the city government moves to a qualitatively new level, new types of services for citizens appear. Generation 2.0 of smart cities has been implemented in Busan (South Korea), Barcelona (Spain), and Rio de Janeiro (Brazil).

In Rio de Janeiro, City Hall has launched a joint project with IBM to implement a monitoring system to prevent landslides in the favelas located on the slopes of the hills. Later, a full-fledged operations center was created based on the information platform. It not only predicted the weather but also received data from various service organizations, allowing it to respond to any emergency, including crime and accidents. IBM notes that in the project, the company was not just a developer and service provider, but a full-fledged 
adviser to the mayor. The solutions tested in Rio are planned to be sold to other cities. Therefore, the implementation of Smart Cities 2.0 projects is appropriate if the technological tools are specifically designed to address issues such as pollution, sanitation, health, and transport, in agreement with their citizens. Unfortunately, the participation of citizens in decision-making is imperfect, as it involves only a small minority.

That is why the next generation of smart cities is addressing the challenges of social inclusion, ensuring equal access to technology, as well as budget savings and environmental protection. Therefore, Smart City 3.0 tries to combine citizens' participation with both government goals and new technologies. Francesca Bria, the Chief Technology Officer (CTO) of Barcelona, promotes a "strategy for digital sovereignty". She believes that the fairest way to advance technology is to involve local communities in their development and the ultimate vision of how they can improve people's quality of life. Residents are actively involved in local projects such as share opinions and supplement the data of various services. For example, in the cities of the future, residents, measuring the quality of air in playgrounds or throughout the area, agree on joint efforts for additional landscaping and new pedestrian areas [15].

According to Juniper Research and Intel, Singapore is the world's leading smart city. It leads the top 20 smart cities in the world, ahead of London, New York, San Francisco, Chicago, and Seoul. In 2019, out of 102 cities in the world, Singapore officially won the title of the "smartest city" according to the first edition of the IMD Smart City Index 2019 (SCI). The $\mathrm{SCl}$ is presented by the IMD World Competitiveness Center's Smart City Observatory on 3 October 2019, in partnership with Singapore University of Technology and Design (SUTD) [22]. The ten smartest cities of 2019 are as follows: Singapore, Zurich, Oslo, Geneva, Copenhagen, Auckland, Taipei, Helsinki, Bilbao and Düsseldorf. The rating is compiled not only based on technological advances but also on the results of a study of the overall quality of life. Four such criteria as mobility, quality of medical care, the safety of life, and productivity were evaluated. Singapore won in all nominations.

The essence of smart Singapore is not only its virtuality. This is a city where the introduction of smart systems is the National Smart Program [16]. Efforts have been made to implement this project not only by non-governmental organizations or companies involved in telecommunications and digital technology but also by the public and the government.

A smart transport system is not just smart stops and buses. These are startups like nuTonomy, which, with the support of the government, are testing self-driving vehicles, which the Singapore authorities plan to introduce as soon as possible. In Singapore, there is an unmanned subway Mass Rapid Transit (MRT). Through an application, you can check the time of arrival of the bus and the number of vacant seats in it. At most of the crossings, some devices extend the duration of the green traffic lights for the elderly and people with limited mobility. The Singaporean government has made significant progress in caring for the elderly, who are provided with mobile devices that monitor their health and call doctors if necessary. Rooms with the elderly are equipped with sensors: if the sensors stop recording the movement, a warning signal is sent to relatives or social services. The system has not yet been put into mass operation, but its testing is free.

Smart healthcare solutions are Telehealth which is remote healthcare that allows consulting and receiving treatment at home. Thanks to specially designed tablets that 
record movements through cameras and sensors, therapists examine and analyze the patient's condition. This is one of the ways how Singaporeans recover after a stroke. It is also an online platform that stores health records and interacts with health information systems and government agencies (ministries and emergency departments).

Hospitals are mastering remote diagnostic systems: they transmit information about a person's condition via wireless networks from sensors on the patient's body. The city has introduced an intelligent sanitary control system based on a video system and computerized containers for waste collection. Singapore's public services portal offers 650 online services: communication with municipal services can be synchronized by a citizen to one mailbox.

Singapore has even created an application that can be used if necessary to receive first aid or help with heart attacks. By clicking on the button, the user notifies people within reach, including healthcare professionals in case of a critical situation.

Smart systems in interaction with the state are online platforms of the government and departments that minimize the need to visit governmental institutions. These include services such as opening a bank account, registering the child's birth, and applying to the kindergarten through a mobile application.

At the same time, smart Singapore is primarily smart homes. For example, thousands of sensors were installed in one area of the city, allowing the authorities to measure energy, waste generation, and water use in real-time, and residents to receive feedback to regulate the use of resources at home.

Conclusion. A smart city is a process that involves the improvement of various aspects of city life based on information technology. And not for the sake of technology itself, but to make the functioning of the city more efficient, and the life of citizens more comfortable and safer. Considering the stages of development of the concept of a smart city, it can be argued that there should be a clearer and faster way to the wider implementation of proven technologies and solutions. It is necessary to understand how to identify the right business models and implementation strategies for this concept. At the same time, urban strategies are increasingly focusing on climate resilience and adaptation, and the development of a smart city that is relevant to citizens and their daily lives. Global revenue from smart cities is expected to grow from US $\$ 36.8$ billion in 2016 to US $\$ 88.7$ billion by 2025 . Thus, the concept of a smart city is not only implemented in the framework of single projects but also included in the strategic development of large city plans. Digital innovations, such as Big Data and the Internet of Things, are becoming roadmaps for increasing human capital and the technological boom of the entire city. These examples show through how strategic initiatives and active city leaders will overcome barriers to urban development. Thus, to date, different countries, leading international organizations and companies share a common vision of the concept of "smart city". In our opinion, now the concept of "smart city" is becoming more stable and flexible; involves the public, applies common leadership methods; works at the intersection of different spheres of life and urban subsystems; effectively uses the collected data; activates the level of implementation of environmental protection processes; aims to improve the quality of services and living standards of citizens. Unfortunately, there is no unanimous opinion as to which of the cities is a model "smart city". But one of the main conclusions is that the government and business of big cities 
should learn from each other, share competencies and experiences. Citizens of megacities should decide how to apply this knowledge. One of the few cities that has risen to this level was Singapore: in the spring of 2019 , it topped the smart city rankings, compiled by the research company Juniper Research and Intel.

In Ukraine, the implementation of the concept of "smart city" began in 2015, when Kyiv authorities announced the project "Kyiv Smart City 2020". Kyiv's global goal is to become one of the most technologically advanced smart cities in the world. Later, other cities in Ukraine, including Kharkiv, Lviv, Vinnytsia, Ternopil, and Odesa, declared their desire to become a smart city. Therefore, the focus of our further research will be the smart city initiatives in Ukraine. In particular, it is advisable to focus on studying the experience of implementing Generation 3.0 in cities that lead the world rankings of smart cities and ways of implementation in Ukraine, because, at today's pace of urbanization, smart cities are the basis of economic prosperity and social progress.

\section{References}

1. World Urbanisation Prospects 2018. Retrieved from https://www.un.org/ development/desa/en/news/population/2018-revision-of-world-urbanizationprospects.html [in English].

2. Hall, T., Hubbard, P. (1998). The entrepreneurial city: Geographies of politics, regime, and representation. New York: John Willey \& Sons [in English].

3. BSI (the British Standards Institution). The Role of Standards in Smart Cities Issue 1, June 2013 [in English].

4. 4. Dialogue of Civilizations Research Institute (DOC Research Institute). Retrieved from https://doc-research.org/ru/speaker/ Rob van Kronenburg [in English].

5. Cisco. Cisco and New Songdo International City Join Forces to Create One of the Most Technologically Advanced Smart Connected Communities. News release, July 6, 2011. Retrieved from https://newsroom.cisco.com/press-releasecontent?articleld=426592 [in English].

6. Harrison, C., Eckman, B., Hamilton, R., Hartswick, P., Kalagnanam, J., Paraszczak, J., \& Williams, P. (2010). Foundations for Smarter Cities. IBM Journal of Research and Development, 54(4) [in English].

7. Washburn, D., Sindhu, U., Balaouras, S., Dines, R. A., Hayes, N. M., \& Nelson, L. E. (2010). Helping CIOs Understand "Smart City" Initiatives: Defining the Smart City, Its Drivers, and the Role of the ClO. Cambridge, MA: Forrester Research, Inc. Retrieved from http://public.dhe.ibm.com/partnerworld/pub/smb/smart erplanet/ forr_help_cios_und_smart_city_initiatives.pdf [in English].

8. A Short History of Big Data. Retrieved from https://datafloq.com/read/big-datahistory/239 [in English].

9. Ashton, K. That Internet of Things. https://www.rfidjournal.com/that-internet-ofthings-thing [in English].

10. Giffinger, R., Fertner, C., Kramar, H., Kalasek, R., Pichler-Milanovic, N., Meijers, E. (2007): Smart Cities - Ranking of European medium-sized cities. Vienna University of Technology, 2007 [in English]. 
11. Goldenberg, S. Masdar's zero-carbon dream could become world's first green ghost town. Retrieved from https://www.theguardian.com/environment/2016/feb/16/masdarszero-carbon-dream-could-become-worlds-first-green-ghost-town [in English].

12. Newcombe, T. Santander: The Smartest Smart City. Governing, May 2014, Retrieved from http://www.governing.com/topics/urban/gov-santander-spain-smartcity.html [in English].

13. Prior, B. Masdar Visit: Solar Projects in Abu Dhabi. Retrieved from https://www. greentechmedia.com/articles/read/update-on-the-masdar-initiative-from-abu-dhabi [in English].

14. Arbes, R. and Bethea, Ch. Songdo, South Korea: City of the Future? The Atlantic, September 27, 2014. Retrieved from https://www. theatlantic.com/international/ archive/2014/09/songdo-south-korea-the-city-of-the-future/380849 [in English].

15. Bria, F. Our data is valuable. Here's how we can take that value back. The Guardian. Retrieved from https://www.theguardian.com/commentisfree/2018/apr/05/datavaluable-citizens-silicon-valley-barcelona [in English].

16. Tham, I. Smart Nation Push to See $\$ 2.8$ Worth of Tenders This Year. The Straits Times, May 24, 2016. Retrieved from http://www.straitstimes.com/singapore/smartnation-push-to-see-28b-worth-of-tenders-this-year [in English].

17. Chourabi, H., Nam, T., Walker, S., Gil-Garcia, R., Nahon, K., Pardo, T., Jochen, H. Scholl (2012). Understanding Smart Cities: An Integrative Framework. 2012. 45th Hawaii International Conference on System Sciences [in English].

18. Caragliu, A., Del Bo, C. \& Nijkamp, P. (2011). Smart cities in Europe. Journal of Urban Technology, 18(2), pp.65 - 82 [in English].

19. Nam, T. \& Pardo, T. (2011). Conceptualizing smart city with dimensions of technology, people, and institutions. Proceedings of the 12th Annual International Digital Government Research Conference on Digital Government Innovation in Challenging Times. College Park, Maryland, June 12-15. 282 p. [in English]

20. Richter, Ch. (2015). Digital collaborations and entrepreneurship - the role of shareconomy and crowdsourcing in the era of smart city. Lappeenranta University of Technology 2016. 214 p. [in English]

21. Hutchinson, W. How Smart is Your "Smart City" and Why Should You Care? Retrieved from: https://bricsmagazine.com/en/articles/how-smart-is-your-smartcity-and-why-should-you-care [in English].

22. IMD Smart City Index 2019. Retrieved from https://www.imd.org/smart-cityobservatory/smart-city-index [in English].

23. Smart cities: world's best don't just adopt new technology, they make it work for people. Retrieved from https://www.weforum.org/agenda/2019/10/smart-cities-worlds-best-don-t-just-adopt-new-technology-they-make-it-work-for-people [in English].

24. Navigant Research. Retrieved from https://www.prnewswire.com/news-releases/ navigant-research-leaderboard-report-smart-city-suppliers-assessment-ofstrategy-and-execution-for-16-smart-city-suppliers

Статтю отримано 4 травня 2020 р.

Article received May 4, 2020. 